\title{
ON THE TOXIC SUBSTANCES FROM VIRULENT PNEU- MOCOCCI AND PNEUMONIC LUNGS AND THE INFLUENCE THEREON OF QUININ AND UREA HYDROCHLORID, ETHYLHYDROCUPREIN HYDROCHLORID, AND OTHER CINCHONA DERIVATIVES
}

$$
\text { STUDIES IN PNEUMONIA, VI }
$$

S. Solis-Cohen, Charles Weiss, and John A. Kolmer From the McManes Laboratory of Experimental Pathology of the Unicersity of Pennsylvania, Philadelphia

\section{INTRODUCTION}

In clinical studies of the beneficial influence of quinin salts and allied compounds in the pneumonias of man, three facts stand out: (1) The relief to toxic symptoms without appreciable influence on the evolution of physical signs, (2) the change of termination from crisis to lysis, and (3) the absence of cinchona poisoning, even when enormous doses are given. (This does not apply to ethylhydrocuprein, however). There is nothing in the known pharmacologic influence of quinin as a function modifier that will account for either the first or the second of these facts. Nor can bactericidal action alone explain them. The third fact indicates the presence of a quinin-tolerance in the subjects of pneumonia.

Hence the hypothesis has been put forth of a possible neutralizing influence of the drug; i. e., a mutual antagonization or inhibition, physical or chemical, direct or indirect, of quinin by pneumonia poison-complex, and of pneumonia poison-complex by quinin. ${ }^{1}$

The term pneumonia poison-complex rather than pneumotoxin, has been used, because it is not accurately known just what are the poisons present in pneumonia-whether they are all of microbic origin directly or indirectly, or whether they are produced in part or in whole by the human organism. The main facts being unknown, the details as to site of production, manner of distribution, chemical and biologic nature, action, etc., can only be conjectured; and no opinion can be

Received for publication Jan. 9, 1918.

Aided by the Fels grant for research in pneumonia.

1 Solis-Cohen, S.: N. Y. Med. Jour., 1916, 103, p. 1065. 
hazarded as to whether the poisons belong wholly to offensive reactions or in part to defensive ones.

To test the hypothesis of the special relation of pneumonia poisons to quinin, therefore, involves much groping in the dark, in the process of establishing or eliminating various possibilities; and an endeavor to find the poison or poisons in question should logically precede such investigations.

It has been deemed practicable, however, to pursue the two lines of research together, partly in the hope that one might throw light on the other; and partly that at least certain preliminary questions as to the possible action of quinin might be determined.

\section{THE PNEUMOTOXIN}

In the attempt to isolate the substance responsible for the toxic symptoms in the pneumonias of man, investigators have focussed their attention on the pneumococcus. Neufeld and Dold ${ }^{2}$ showed that by the action in vitro of complement on the precipitate resulting from the addition of pneumococci to the corresponding immune serum, a toxic substance is produced which, on primary intravenous injection into guinea-pigs produces anaphylactic-like symptoms and death. They concluded that this anaphylatoxin of Friedberger ${ }^{3}$ is set free by the body fluids and that pneumonia is a "mild and protracted form of anaphylaxis." Vaughan and Wheeler ${ }^{4}$ give a similar explanation, based on their studies of protein products. Rosenow ${ }^{5}$ thinks that the autolytic products of the pneumococcus which he demonstrated in vitro in the absence of serum, and which are similar in their properties to the anaphylatoxin of Friedberger, are liberated in vivo by the ferments in the bacterial cell. But as pointed out by Cole, who gives a complete review of the literature, ${ }^{6}$ the symptoms produced by the injection of anaphylatoxin or bacterial extract resemble very remotely those presented during a pneumococcus infection. Furthermore, Cole found that even when autolysis of the pneumococci is prevented by dissolving large masses of them in sodium choleate, a highly toxic and hemolytic substance is liberated which produces anaphylactic symptoms and death on primary injection into guinea-pigs. He concludes that the pneumococcus poison exists preformed in the bacterial cell

2 Dold, H.: Das Bakterienanaphylatoxin, 1912.

3 Ztschr. f. Immunitätsforsch., 1909, 2, p. 208; 3, p. 692; 1910, 4, p. 636.

4 Jour.. Infect. Dis., 1907, p. 476.

5 Ibid., 1911, 9, p. 190; 1912, 10, p. 113.

B Jour. Exper. Med., 1912, 16, p. 644. 
and that its liberation depends not on the action of its own autolytic ferments, but on the dissolution of the pneumococcus by the body fluids.

What part this endocellular pneumococcus toxin plays in the symptom-complex and changes in pneumonia is a matter of conjecture. It is possible that its continuous liberation in vivo (presumably accomplished with facility by the action of the tissue enzymes: trypsin, leukoproteases, etc.) may result in the initial toxemia manifest in general disturbances such as cardiac, respiratory and vasomotor symptoms. The pneumotoxin, moreover, increases the permeability of the walls of the capillaries lining the alveoli for the various blood proteins, erythrocytes, leukocytes, fibrin and enzymes. Friedrich Müller ${ }^{7}$ has shown that the enzymes in the exudate are introduced from without and are foreign to the lung tissue. These normal constituents of the circulating body fluids, when transferred to and accumulated in the alveolar spaces form the exudate. We have shown elsewhere ${ }^{8}$ that the pneumonic exudate is composed of normal serum proteins. The extreme leukocytosis. in pneumonia favors this phenomenon.

With the body fluids depleted of their normal proteins, there is a diminution in their osmotic pressure, as shown by Sandelowsky, ${ }^{9}$ Achard, Tourraine and Saint Girons, ${ }^{10}$ Epstein, ${ }^{11}$ and Rowe. ${ }^{12}$ To compensate for this there is the retention of chlorids, long clinically known and recently studied by Rowntree, ${ }^{13}$ Medigreceanu ${ }^{14}$ and Peabody: ${ }^{15}$ which keeps the osmotic pressure constant.

It may be further assumed that pneumococci proliferating in the body fluids liberate the proferments that initiate the autolysis of the fibrin, leukocytes, etc., in the lung. Taylor ${ }^{16}$ points out that bacterial extracts and tissue juices activate proferments such as propepsin. The toxic products, however, tend to inhibit this autolysis with the production of only partly digested products such as albumoses, proteoses and peptones, as observed by Turro, ${ }^{17}$ Matthes, ${ }^{18}$ Levaditi, ${ }^{19}$ Pouchet, ${ }^{20}$ and

7 Verhandiung der Naturforschenden Gesellschaft in Basel, 1902, 13.

${ }^{8}$ Weiss, Charles, et al.: The Mechanism of the crisis in pneumonia (to be published).

\& Deutsch. Arch. f. klin. Med., 1909, 96, p. 455; 1910, 100, p. 324.

14 Arch. de Med. Exper. et d'anat. Path., 1912, 24, p. 647.

11 Am. Jour. Med. Sc., 1917, 154, p. 638.

12 Arch. Int. Med., 1917, 18, p. 455.

18 Bull. Johns Hopkins Hosp., 1908, 19, p. 367.

14 Jour. Exper. Med., 1911, 14, p. 289.

15 Jour. Exper. Med., 1913, 17, p. 71.

18 Digestion and Metabolism, 1912.

17 Centralbl. f. Bakteriol., 1912, 32, p. 105.

18 Arch. f. exp. Path. u. Pharm., 1895, 36, p. 437.

19 Ann. de l'Inst. Pasteur, 1903, 17, p. 187.

201883,96, p. 1506 and 1601. 
Auld. ${ }^{21}$ These products are toxic. They aid in further inhibition of autolysis and when absorbed, increase the coagulation time of the blood, as shown by Dochez, ${ }^{22}$ Hayem, ${ }^{23}$ Pye-Smith, ${ }^{24}$ and Coleman, ${ }^{25}$ $\mathrm{Opie}^{26}$ has furthermore shown that the serum of inflammatory exudates retards the action of the autolytic enzymes within the leukocytes.

The period of accumulation of greatest amount of pneumotoxin and hence of toxic albumoses, proteoses, etc., is the period of the crisis. As the pneumococci continue to proliferate, the increasing amount of acid (as pointed out by Netter, Bougault and Salanier, ${ }^{27}$ and of bactericidal substances in the exudate (observed by Conradi ${ }^{28}$ ) combined with the phagocytic action of the leukocytes (Lamar and Meltzer, ${ }^{29}$ Tschistovitch, ${ }^{30}$ Winternitz and Hirschfelder, ${ }^{31}$ Winternitz and $K$ Kline $^{32}$ ), and the production of various antibodies (observed by Clough, ${ }^{33}$ Dochez, ${ }^{34}$ Jobling, ${ }^{35}$ Rosenow, ${ }^{5}$ Cole ${ }^{36}$ Bull ${ }^{37}$ and others) checks their growth and toxin production. That antibodies may be formed to the toxin itself in addition to other antibodies, is suggested by the increase of the globulins of the serum (Rowe ${ }^{12}$ and Epstein ${ }^{38}$ ), a phenomenon which is generally found to be associated with antibody formation, as shown by Hurwitz and Meyer, ${ }^{39}$ Banzhaf and Gibson, ${ }^{40}$ Gibson and Collins ${ }^{41}$ and others.

Moreover, the continuous action of the toxins, aside from antibody production, changes the primary inhibitory effect on autolysis into an accelerating one. This is suggested by the work of Hess and

21 Selected Researches in Pathology, 1901.

22 Jour. Exper. Med., 1912, 16, p. 693.

23 Du sang et de ses alterations anatomiques, 1889.

24. Allbut and Rolleston, System of Medicine, 1898, 5, p. 91.

25 Biochem. Tour., 1907, 2, p. 184.

26 Jour. Exper. Med., 1905, 7, p. 316.

27 Compt. rend Soc. de Biol., 1917, p. 80, and 97.

28 Beitr. z. Chem. Physiol. u. Path., 1901, 1, p. 193.

29 Jour. Exper. Med, 1912, 15, p. 133.

30 Ann. de 1'Inst. Pasteur, 1890, 4, p. 285 ; 1904, 18, p. 304.

31 Jour. Exper. Med., 1913, 17, p. 657.

32 Ibid., 1915, 21, p. 320.

a3 Bull. Johns Hopkins Hosp., 1913, 24, p. 295.

s4 Jour. Exper. Med., 1912, 16, p. 665.

ss Ibid., 1915, 22, p. 568.

se Ibid., 1914,20 , p. 346 .

37 Ibid., 1915, 22, p. 457.; 1916, 24, p. 7.

ss Ibid., 1912, 16, p. $719 ; 1913,17$, p. $444 ; 1914,20$, p. 334.

sa Ibid., 1916,24 , p. 515 .

40 Ibid., 1910, 12, p. 3. Gibson and Famulaner, L. W.: Collected Studies, Bureau of Laboratories, Dept. of Health, City of New York, 1915, 8, p. 208.

$₫ 1$ Jour. Biol. Chem., 1907, 3, p. 232. 
Saxl. ${ }^{42}$ This accelerated autolysis in turn hastens antibody production as pointed out by Blum. ${ }^{43}$ The products of autolysis are now completely digested proteins in the amino-acid stage which are nontoxic and easily absorbed and eliminated.

The transition from inhibitory to accelerating action of pneumotoxin on autolysis is governed by the laws of mass action. Hence the change from febrile toxemia to the afebrile atoxic state is necessarily an abrupt one - crises. The period is marked by the sudden drop in temperature and relief from toxemic symptoms and return to normal coagulation time of the blood. It is clinically a period of peril, and may terminate in death-a fact not to be lost sight of in analysis or in experimental study. If successfully passed, resolution sets in, with removal (autolysis) of exudate.

The autolysis is probably accomplished by the normal proteolytic enzymes of the body. Hartman ${ }^{44}$ suggests that the fibrin requires specific antibodies for its removal, and Ascoli ${ }^{15}$ is of the opinion that isolysins are formed to remove the cellular constituents. He demonstrated such isolysins after the crisis.

That the pneumotoxin exerts no influence on the lung tissue itself and that the latter plays no part in the formation of the exudate is well known, as mentioned by Wells. ${ }^{46}$ Our own observations ${ }^{8}$ based on various anaphylactic and chemical studies substantiate this.

Views similar to this have been expressed by $\mathrm{Hedin}^{47} \mathrm{Opie}^{26}$ Jobling and Peterson, ${ }^{35}$ Dick, ${ }^{48}$ Hektoen, ${ }^{49}$ and Falls. ${ }^{50}$ At present we are engaged in subjecting the various phases of our hypothesis to experimentation.

The opinion that the exudate plays an important and specific rôle in lobar pneumonia is indicated by the work of Rosenow and Arkin ${ }^{51}$ who showed that extracts of pneumonic lungs injected intravenously into dogs delay the coagulation time of the blood, and produce symptoms simulating anaphylaxis. Our own, work on the comparative toxicity of normal and pneumonic lungs described elsewhere ${ }^{52}$ demon-

42 Wiener klin. Wchschr., 1908, 21, p. 248 and 486.

43 Beitr. z. chem. Physiol. u. Path., 1904, 5, p. 142.

44 Jour. Infect. Dis., 1913, 13, p. 69 and 499.

4s München. med. Wchnschr., 1901, 48, p. 1241.

16 Chemical Pathology, 1914.

${ }_{47}$ Ztschr. f. physiol. Chem., 1907, 52, p. 412.

48 Jour. Infect. Dis., 1912, 10, p. 383.

4 Jour. Am. Med. Assoc., 1914, 62, p. 254.

so Jour. Infect. Dis., 1915, 16, p. 466.

$\$ 1$ Jour. Infect. Dis., 1912, 11, p. 480.

5 Kolmer, J. A., Weiss, C., and Steinfield, E.: Jour. Infect. Dis., 1918, 22, p. 469. 
strates the toxicity of the pneumococcus exudate. We have, furthermore, obtained specific anaphylactic reactions in guinea-pigs sensitized to such extracts. We shall report on this and other corroborative evidence in another paper. ${ }^{8}$

These two substances, the pneumococcus hemotoxin and the toxic extract of a pneumonic lung, seemed to afford a point of attack in the problem of the action of quinin on pneumococcic poisons in general, and the observations which are set forth in detail in this paper were made to determine whether any neutralizing action could be demonstrated.

\section{Is There a Neutralizing Power of Quinin and Its Congeners on PNeumotoxin?}

Technic of Preparation of Pneumotoxin.-The demonstration of an endocellular toxin in the pneumococcus is fraught with many difficulties. The virulence of the organism, the mediums in which it is grown, the temperature and time of incubation, the amount of autolysis, the presence of traces of broth proteins, the thickness of the emulsion of pneumococci, the volume of choleate used, and a host of other details determine the success or failure of the preparation of the pneumococcus toxin. In spite of the fact that we followed in detail the precautions mentioned by Cole, we were unable to produce uniformly a toxin which was hemolytic and also produced anaphylaxis on primary intravenous injection in guinea-pigs. Our results with rats were almost uniformly negative, probably due to the extremely high tolerance of the rat for anaphylatoxins. This subject has been recently studied by Novy and his associates. ${ }^{\mathrm{ss}}$

The organism used was pneumococcus Type I obtained from Dr. Rufus Cole. It was grown in tubes of beef infusion broth containing $0.1 \%$ glucose and $1 \%$ Witte's peptone to which was added a drop of freshly defibrinated human, horse or rabbit blood. The reaction of the medium was slightly alkaline to phenolphthalein.

It was found advisable, in order to obtain a luxuriant and virulent culture, to transplant every other day, and from time to time, to pass the organism through a mouse. In this way the M. L. D. for mice (24 hours) was kept constantly at $0.000,000,1 \mathrm{cc}$ of a 24 -hour broth culture.

The technic employed was briefly as follows: 1,000 to $1,500 \mathrm{cc}$ of a $24-\mathrm{hour}$ broth culture was centrifugalized for 30-60 minutes at high speed. The bacterial sediment was washed once in salt solution $(0.85 \%)$ and after a second centrifugalization the supernatant fluid was completely removed. To the sediment were added $5 \mathrm{cc}$ of salt solution and $5 \mathrm{cc}$ of a mixture of $2 \%$ solutions of primary and secondary sodium phosphate $(1: 8)$. To the thick emulsion thus obtained was added 1-2 $\mathrm{c} c$ of a $2 \%$ solution of sodium choleate (in normal salt solution). This mixture was placed in a $37 \mathrm{C}$. water-bath for one-half hour and frequently stirred; the total volume was now made up to 75 or $100 \mathrm{cc}$ with salt solution and the resulting mixture kept in the refrigerator until used.

A control fluid containing sodium choleate and primary and secondary sodium phosphate was prepared in exactly the same way. The volume of pneumococcus emulsion was of course replaced by salt solution.

ss Novy, DeKruif, et al.: Jour. Infect. Dis., 1917, 20, p. 498. 
The Toxicity of Pneumotoxin by Animal Injection.-The toxicity of the pneumotoxin was tested by intravenous injection in guinea-pigs and white rats and by intraperitoneal injection in white mice. When injecting pneumotoxin intraperitoneally into mice, it became extremely important to culture the fluid for purpose of ascertaining whether or not any pneumococci had escaped solution in the sodium choleate, and also to culture the heart's blood of all mice dying as a result of injection. The results are given in Tables 1 and 2 .

TABLE 1

Toxicity of Pneumotoxin by Intravenous Injection In Guinea-Pigs*

\begin{tabular}{|c|c|c|c|}
\hline $\begin{array}{l}\text { Pneumo- } \\
\text { toxin } \\
\text { No. }\end{array}$ & $\begin{array}{l}\text { Weight of } \\
\text { Animal } \\
\text { in Grams }\end{array}$ & $\begin{array}{c}\text { Dose } \\
\text { Injected } \\
\text { in } \mathrm{Ce}\end{array}$ & Results \\
\hline $\begin{array}{c}1 \\
1 \\
1 \\
\text { Control fluid 1 } \\
2 \\
2 \\
2 \\
2 \\
2 \\
\text { Control fluid } 2 \\
\text { Control fluid } 2 \\
9 \\
9 \\
10 \\
10 \\
10\end{array}$ & $\begin{array}{l}350 \\
400 \\
320 \\
315 \\
210 \\
205 \\
200 \\
205 \\
200 \\
180 \\
205 \\
265 \\
270 \\
310 \\
300 \\
255\end{array}$ & $\begin{array}{l}6 \\
6 \\
6 \\
6 \\
2 \\
2 \\
2 \\
2 \\
5 \\
2 \\
2 \\
3 . \\
8.5 \\
5.5 \\
6.5 \\
5.5 \\
4.5\end{array}$ & $\begin{array}{l}\text { Immediate anaphylactic death } \\
\text { Anaphylactic symptoms with death in } 24 \text { hrs. } \\
\text { Anaphylactic symptoms with death in } 24 \text { brs. } \\
\text { No symptoms } \\
\text { Died. } 24 \text { hours } \\
\text { Died. } 24 \text { hours } \\
\text { Died. } 48 \text { hours } \\
\text { Died. } 24 \text { hours } \\
\text { Died. } 72 \text { hours } \\
\text { Died. } 24 \text { hours } \\
\text { Died. } 24 \text { hours } \\
\text { Dyspnea; died in } 5 \text { days } \\
\text { Slight toxic symptoms; recovered } \\
\text { Severe dyspnea; recovered } \\
\text { Moderate shock } \\
\text { Mild dyspnea; recovered }\end{array}$ \\
\hline
\end{tabular}

* All animals were observed for a period of one week.

TABLE 2

Toxicity of Pneumotoxin by Intraperitoneal Injection

\begin{tabular}{|c|c|c|c|c|c|c|c|}
\hline \multicolumn{4}{|c|}{ Mice } & \multicolumn{4}{|c|}{ Rats } \\
\hline $\begin{array}{l}\text { Pneu- } \\
\text { mo- } \\
\text { toxin } \\
\text { No. }\end{array}$ & $\begin{array}{l}\text { Weight } \\
\text { of Ani- } \\
\text { mal in } \\
\text { Grams }\end{array}$ & $\begin{array}{c}\text { Dose } \\
\text { per } \\
100 \\
\text { Grams }\end{array}$ & Results & $\begin{array}{l}\text { Pneu- } \\
\text { mo- } \\
\text { toxin } \\
\text { No. }\end{array}$ & $\begin{array}{l}\text { Weight } \\
\text { of Ani- } \\
\text { mal in } \\
\text { Grams }\end{array}$ & $\begin{array}{c}\text { Dose } \\
\text { per } \\
100 \\
\text { Grams }\end{array}$ & Results \\
\hline $\begin{array}{c}4 \\
4 \\
4 \\
\text { Contral } \\
\text { fluid } 4\end{array}$ & $\begin{array}{l}19 \\
20 \\
20 \\
20\end{array}$ & $\begin{array}{l}1.0 \\
0.5 \\
0.06 \\
1.0\end{array}$ & $\begin{array}{l}\text { Died, } 24 \text { hours } \\
\text { Died, } 24 \text { hours } \\
\text { Died, } 24 \text { hours } \\
\text { Survived }\end{array}$ & $\begin{array}{c}6 \\
6 \\
6 \\
6 \\
\text { Control } \\
\text { fluid } 6\end{array}$ & $\begin{array}{l}84 \\
81 \\
82 \\
75 \\
70\end{array}$ & $\begin{array}{l}5.0 \\
4.0 \\
2.5 \\
2.0 \\
\\
4.0\end{array}$ & $\begin{array}{l}\text { Dyspnea; recovered } \\
\text { No symptoms } \\
\text { No symptoms } \\
\text { No symptoms } \\
\text { No symptoms }\end{array}$ \\
\hline
\end{tabular}

The Neutralizing Power of Quinin and Its Compounds on Pneumotoxin in $V i z o .-A f t e r$ having thus determined the lethal dose of each preparation of pneumotoxin, we attempted to neutralize its toxicity by means of the various cinchona derivatives, using the following methods:

1. In Vitro: The toxin and drug were mixed in the test tube in proper proportions and incubated either at room temperature or at $37 \mathrm{C}$. for 1,2 or 3 hours and injected. The in vitro method had to be abandoned for it was observed that sodium choleate, protein solutions and colloidal suspensions (such as agar, 
saponin and gum mastic) as well as serum will precipitate quinin. The latter substance is mentioned by MacGilchrist. ${ }^{54}$

2. In Vivo: The proper amount of drug was injected into the animal 2 or more hours before the injection of the toxin.

The results are summarized in Tables 3 and 4.

TABLE 3

Neutralizing Power of Cinchona Derivatrves for the Toxicity of Pheumotoxin

\begin{tabular}{|c|c|c|c|c|c|}
\hline \multirow{2}{*}{$\begin{array}{c}\text { Weight of } \\
\text { Animal } \\
\text { in Grams }\end{array}$} & \multicolumn{2}{|c|}{ Pneumotoxin } & \multirow{2}{*}{ Quinin Salt } & \multirow{2}{*}{$\begin{array}{l}\text { Dose of } \\
\text { Quinin per } \\
60 \text { Kilo }\end{array}$} & \multirow{2}{*}{ Results } \\
\hline & No. & Dose & & & \\
\hline 185 & 2 & $5 \mathrm{ec}$ & $\begin{array}{l}\text { Ethylhydrocuprein } \\
\text { hydrochlorid }\end{array}$ & $1 . \overline{5}$ & $\begin{array}{l}\text { Anaphylactic; death } \\
5 \text { minutes }\end{array}$ \\
\hline 195 & 2 & $5 \mathrm{cc}$ & $\begin{array}{l}\text { Quinin and urea } \\
\text { hydrochlorid }\end{array}$ & 1.5 & Died 24 hours \\
\hline $19 \overline{5}$ & Control & 0 & $\begin{array}{c}\text { Ethylhydrocuprein } \\
\text { hydrochlorid }\end{array}$ & 1.5 & No symptoms \\
\hline 19.5 & Control & 0 & $\begin{array}{l}\text { Quinin and urea } \\
\text { hydrochlorid }\end{array}$ & $1 . \overline{5}$ & No symptoms \\
\hline
\end{tabular}

Pneumotoxin and quinin salt were incubated at room temperature for one hour and injected intravenously into guinea-pigs.

TABLE 4

Neutralizing Power of Cinchona Derivatives for the Toxicity of Pneumotoxin

\begin{tabular}{c|c|c|c}
\hline $\begin{array}{c}\text { Weight in } \\
\text { Grams }\end{array}$ & Dose of Cinchona & \\
& Name of Salt & $\begin{array}{c}\text { Grams per } \\
60 \text { Kilo }\end{array}$ & Results \\
\hline
\end{tabular}

In Vitro

\begin{tabular}{|c|c|c|c|}
\hline $\begin{array}{l}18 \\
16 \\
19 \\
21\end{array}$ & $\begin{array}{l}\text { Ethylhydrocuprein hydrochlorid } \\
\text { Ethylhydrocuprein hydrochlorid } \\
\text { Quinin and urea hydrochlorid } \\
\text { Quinin and urea hydrochlorid }\end{array}$ & $\begin{array}{l}2.0 \\
1.0 \\
2.0 \\
1.0\end{array}$ & $\begin{array}{l}\text { Died, } 24 \text { hours } \\
\text { Died, } 24 \text { hours } \\
\text { Died, } 24 \text { hours } \\
\text { Died, } 24 \text { hours }\end{array}$ \\
\hline \multicolumn{4}{|c|}{ In Vivo } \\
\hline $\begin{array}{l}16 \\
20 \\
18 \\
18\end{array}$ & $\begin{array}{l}\text { Ethylhydrocuprein hydrochlorid } \\
\text { Ethylhydrocuprein hydrochlorid } \\
\text { Quinin and urea hydrochlorid } \\
\text { Quinin and urea hydrochlorid }\end{array}$ & $\begin{array}{l}1.0 \\
0.5 \\
1.0 \\
0.5\end{array}$ & $\begin{array}{l}\text { Died, } 24 \text { hours } \\
\text { Died, } 24 \text { hours } \\
\text { Died, } 24 \text { hours } \\
\text { Died, } 24 \text { hours }\end{array}$ \\
\hline
\end{tabular}

In Vitro Tests: 2 M.L.D, of pneumotoxin were incubated at $37 \mathrm{cc}$ for 2 hours with the proper dose of quinin and injected intraperitoneally into mice. In Vivo Tests: The proper dose of quinin was injected intraperitoneally and 2 M.L.D. of the pneumotoxin were given in the same way. Controls: Receiving the doses of quinin given in the tables survived; those receiving the pneumotoxin alone died.

As shown in the tables, the cinchona derivatives do not exert any gross neutralizing action on the toxicity of pneumococcus toxin. In vivo experiments conducted with guinea-pigs gave negative or inconstant results. It was thought highly desirable to study the effect of the repeated injection of sublethal doses of the pneumotoxin followed by

${ }^{54}$ Scient. Mem. Off. Med. and Sanit. Depts., India, 1911, No. 41. 
similar doses of the cinchoma derivatives. This slower method of absorption approaches more closely the condition in human pneumonia. But because of the difficulty of preparing the pneumotoxin and of its extreme lability and rapid deterioration this procedure was found impracticable.

Hemolytic Activity of Pneumotoxin.-Cole ${ }^{36}$ showed that the toxin liberated by the dissolution of washed pneumococci in sodium choleate was hemolytic for red blood cells. He found that various normal serums, solutions of egg albumin, cholesterin, lecithin, and trypsin will destroy this hemolytic power; that the inhibitory power of serum of pneumonic patients was no greater than of normal serum.

We attempted to demonstrate any neutralizing action of various quinin salts in relation to the hemolytic action of the pneumotoxin, in the hope that it would throw some light on the influence of the cinchona derivatives in the treatment of pneumonia.

Technic of Hemolytic Tests.-Fresh guinea-pig corpuscles washed free from serum were used in a $1 \%$ suspension in salt solution, and in constant dose of $1 \mathrm{cc}$.

Toxin or poison was made up with salt solution into proper dilution and pipetted in doses ranging from $0.1-2 \mathrm{cc}$.

The total volume in each tube was $3 \mathrm{cc}$.

Incubation was effected either in a $37 \mathrm{C}$. water bath for 1 hour or in a dry incubator at $37 \mathrm{C}$. for 2 hours.

Readings were made at the end of the period of incubation and again after the cells have settled down in the refrigerator over night.

The results obtained are illustrated in Table 5 .

TABLE 5

The Hemolytic Activity of PNeumotoxin

\begin{tabular}{|c|c|c|c|c|c|c|c|}
\hline \multirow{2}{*}{ Substance } & \multicolumn{7}{|c|}{ Dose of Pneumotoxin $\mathrm{Ce}$} \\
\hline & 0.1 & 0.3 & 0.5 & 0.7 & 1.0 & 1.5 & 2.0 \\
\hline 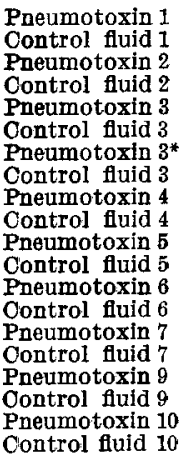 & $\begin{array}{l}\text { NH } \\
\text { NH } \\
\text { VSH } \\
\text { NH } \\
\text { NH } \\
\text { NH } \\
\text { VSH } \\
\text { NH } \\
\text { NH } \\
\text { NH } \\
\text { NH } \\
\text { NH } \\
\text { NH } \\
\text { NH } \\
\text { MH } \\
\text { NH } \\
\text { OH } \\
\text { NH } \\
\text { NH } \\
\text { NH }\end{array}$ & $\begin{array}{l}\text { NH } \\
\text { NH } \\
\text { SH } \\
\text { NH } \\
\text { NH } \\
\text { NH } \\
\text { VSH } \\
\text { NH } \\
\text { NH } \\
\text { NH } \\
\text { NH } \\
\text { NH } \\
\text { NH } \\
\text { NH } \\
\text { OH } \\
\text { NH } \\
\text { OH } \\
\text { NH } \\
\text { NH } \\
\text { NH }\end{array}$ & $\begin{array}{l}\text { NH } \\
\text { NH } \\
\text { SH } \\
\text { NH } \\
\text { OH } \\
\text { NH } \\
\text { OH } \\
\text { NH } \\
\text { NH } \\
\text { NH } \\
\text { NH } \\
\text { NH } \\
\text { SH } \\
\text { SH } \\
\text { OH } \\
\text { NH } \\
\text { OH } \\
\text { SH } \\
\text { NH } \\
\text { SH }\end{array}$ & $\begin{array}{l}\text { NH } \\
\text { NH } \\
\text { MH } \\
\text { NH } \\
\text { OH } \\
\text { NH } \\
\text { OH } \\
\text { NH } \\
\text { NH } \\
\text { NH } \\
\text { SH } \\
\text { SH } \\
\text { MH } \\
\text { OH } \\
\text { OH } \\
\text { MH } \\
\text { OH } \\
\text { MH } \\
\text { VMH } \\
\text { MH }\end{array}$ & $\begin{array}{l}\mathrm{NH} \\
\mathrm{NH} \\
\mathbf{M H} \\
\mathrm{NH} \\
\mathrm{OH} \\
\mathrm{NH} \\
\mathrm{OH} \\
\mathrm{OH} \\
\mathrm{NH} \\
\mathrm{NH} \\
\mathrm{MH} \\
\mathrm{OH} \\
\mathrm{OH} \\
\mathrm{OH} \\
\mathrm{OH} \\
\mathrm{OH} \\
\mathrm{OH} \\
\mathrm{OH} \\
\mathrm{OH} \\
\mathrm{OH}\end{array}$ & $\begin{array}{l}\mathrm{NH} \\
\mathrm{NH} \\
\mathrm{CH} \\
\mathrm{SH} \\
\mathrm{OH} \\
\mathrm{CH} \\
\mathrm{CH} \\
\mathrm{OH} \\
\mathrm{NH} \\
\mathrm{NH} \\
\mathrm{CH} \\
\mathrm{CH} \\
\mathrm{OH} \\
\mathrm{CH} \\
\mathrm{CH} \\
\mathrm{CH} \\
\mathrm{CH} \\
\mathrm{CH} \\
\mathrm{CH} \\
\mathrm{CH}\end{array}$ & $\begin{array}{l}\mathrm{NH} \\
\mathrm{NH} \\
\mathrm{OH} \\
\mathrm{OH} \\
\mathrm{OH} \\
\mathrm{CH} \\
\mathrm{OH} \\
\mathrm{CH} \\
\mathrm{NH} \\
\mathrm{NH} \\
\mathrm{CH} \\
\mathrm{OH} \\
\text { OH } \\
\text { OH } \\
\mathrm{OH} \\
\mathrm{CH} \\
\text { OH } \\
\text { OH } \\
\mathrm{CH} \\
\mathrm{CH}\end{array}$ \\
\hline
\end{tabular}

$\mathrm{NH}=$ no hemolysis; vSH = very slight hemolysis; $\mathrm{SH}=$ slight hemolysis; $\mathbf{M H}=$ marked hemolysis; VMH = very marked hemolysis; $\mathrm{CH}=$ complete hemolysis.

* This pneumotoxin was retested after one week's storage in the refrigerator. 
As shown in Table 5, four of the pneumotoxins (2, 3, 7, and 9) showed a more marked hemolytic activity for guinea-pig cells than the control fluids. Cole points out that the hemolytic and toxic properties of a solution of pneumococci in sodium choleate are not always concomitant. Our findings confirm this opinion. From the results of our attempts at preparing pneumotoxin we are led to believe that the glucose in the culture medium, while essential for the production of the hemolytic properties, interferes with the liberation of the toxic constituents by producing cholic acid from the sodium choleate (Table 6).

TABLE 6

Summary of the Toxic and Hemolytic Propertes of Various Preparations of PNEUMOTOXIN

\begin{tabular}{|c|c|c|c|c|}
\hline $\begin{array}{l}\text { Pneumo- } \\
\text { toxin } \\
\text { No. }\end{array}$ & $\begin{array}{l}\text { Volume of } \\
\text { Broth in } \\
\text { C C }\end{array}$ & $\begin{array}{c}\text { Per Cent. of } \\
\text { Glucose in } \\
\text { Broth }\end{array}$ & $\begin{array}{l}\text { Degree of } \\
\text { Toxicity }\end{array}$ & $\begin{array}{c}\text { Hemolytie } \\
\text { Activity }\end{array}$ \\
\hline $\begin{array}{r}1 \\
2 \\
3 \\
4 \\
5 \\
6 \\
7 \\
9 \\
10\end{array}$ & $\begin{array}{l}1000 \\
1500 \\
1000 \\
2000 \\
1500 \\
1500 \\
1500 \\
1400 \\
1400\end{array}$ & $\begin{array}{c}0.1 \\
0.1 \\
0.1 \\
0.1 \\
\text { None } \\
\text { None } \\
0.08 \\
0.1 \\
\text { None }\end{array}$ & $\begin{array}{c}++ \\
++ \\
0 \\
+ \\
+ \\
+ \\
0 \\
+ \\
+\end{array}$ & $\begin{array}{c}\text { None } \\
++ \\
+++ \\
\text { None } \\
\pm \\
\pm \\
+++ \\
+++ \\
+\end{array}$ \\
\hline
\end{tabular}

+++ Very marked hemolytic activity or toxicity.

++ marked hemolytic activity or toxieity.

+ slight hemolytic activity or toxicity.

\pm doubtful (hemolytic activity no greater than control fluid).

0 not determined.

The Neutralizing Power of Cinchona Derizatives for the Hemotoxin of Pneumococci in Vitro.--In the course of our studies on the neutralizing power of the cinchona derivatives for the hemotoxin of pneumococci, we observed that the solutions of quinin used (1\% in salt solution) were of themselves very hemolytic. This hemolytic activity was partly due to the free acid present in the various soluble salts of quinin. It was found impossible to neutralize this acidity, since the quinin would precipitate on the addition of alkali. The following technic was therefore adopted: The hemolytic activity of the various quinin salts in $0.1 \%$ and $1 \%$ solutions, of the toxin and of the control fluid was titrated for guinea-pig cells. In one series of test-tubes were placed the largest nonhemolytic doses of the various quinin salts; in a second series the smallest hemolytic dose, in a third gradually increasing doses. To each tube of Series 1 and 2 were added increasing doses of toxin. Each tube of Series 3 received 3 M. H. D. of pneumotoxin. The same procedure was repeated using the control fluid. We found that the quinin salts exerted no inhibition on the hemolytic activity of pneumotoxin. In fact the reverse phenomenon, a summation of hemolytic powers was observed.

\section{The Influence of Cinchona Derivatives on the Toxic Substances Obtainable from PNeumonic Lungs}

Preparation of Lung Extracts.-A report of the method of preparation, the comparative toxicity and biologic specificity of human pneumonic lung extracts is given in another communication. ${ }^{.2}$ We wish here briefly to indicate the technic and the results of attempts to neutralize the toxic substance in such extracts: A pneumonic lung in the stage of gray hepatization was obtained as soon as 
possible after necropsy; smears were made from various sections and stained for pneumococci by Gram's stain. The lung tissue was passed through a meat grinder, ground up in a mortar with washed quartz sand and finally squeezed in a Buchner press with a force of $250 \mathrm{~kg}$. per square centimeter. The juice thus obtained was centrifuged, filtered through paper and preserved in the refrigerator with $0.5 \%$ phenol. Injections were made in guinea-pigs, mice and rabbits by intraperitoneal and intravenous routes.

We found that the exudate of human pneumonic lung is highly toxic, producing anaphylactic-like symptoms in guinea-pigs and rabbits and paralysis on repeated intramuscular injection in the latter. This last observation suggests the presence of a toxic albumose such as demonstrated by $\mathrm{Auld}^{91}$ in the tissues of rabbits dying of pneumonic infections.

Summary of the Neutralizing Power of Cinchona Derivatives for the Toxicity of Pneumonic Lung Extracts.-Using both in vitro and in vivo methods it was found that quinin hydrobromid exerted a very marked neutralizing action on the toxicity of pneumonic lung extracts in that therapeutic doses prolonged the life of the animal up to five days or more after the injection of 1 M.L.D. of the extract; quinin hydrochlorid, quinin and urea hydrochlorid and ethylhydrocuprein hydrochlorid afforded little or no protection. The results are shown in Tables 7,8 , and 9 .

TABLE 7

The Neutralizing Power of Various Cinchona Derivatives on the Toxicity of Pneumonic Exudates in Guinea-Pigs

\begin{tabular}{|c|c|c|}
\hline $\begin{array}{l}\text { Weight of } \\
\text { Animal in } \\
\text { Grams }\end{array}$ & Cinchona Compound & Results \\
\hline $\begin{array}{l}175 \\
195 \\
215 \\
200 \\
215 \\
210\end{array}$ & 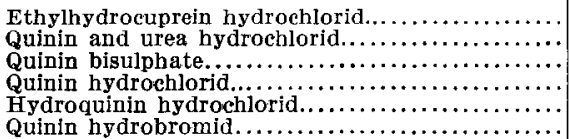 & $\begin{array}{l}\text { Died at once } \\
\text { Died in } 30 \text { minutes } \\
\text { Died in } 6 \text { days } \\
\text { Died in } 2 \text { days } \\
\text { Died at once } \\
\text { Died in } 5 \text { days }\end{array}$ \\
\hline
\end{tabular}

One M.L.D. of pneumonic lung extract was incubated for 2 hours at 37 C. with a dose of cinchona equivalent to $1 \mathrm{gm}$. per kilo of body weight and injected intravenously.

TABLE 8

The Neutralizing Power of Various Cinchona Derivatives on the Toxicity of Pneumonic Exudates in Mice

\begin{tabular}{|c|c|c|c|}
\hline $\begin{array}{c}\text { Weight in } \\
\text { Grams }\end{array}$ & Cinchona Derivative & $\begin{array}{l}\text { Grams of Drug } \\
\text { per } 60 \text { Kilo }\end{array}$ & Results \\
\hline $\begin{array}{l}24 \\
21 \\
17 \\
17 \\
14 \\
18\end{array}$ & 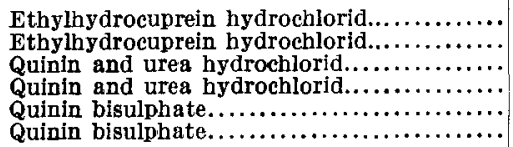 & $\begin{array}{l}2.0 \\
1.0 \\
2.0 \\
1.0 \\
2.0 \\
1.0\end{array}$ & $\begin{array}{l}\text { Died, } 24 \text { hours } \\
\text { Died, } 24 \text { hours } \\
\text { Died, } 24 \text { hours } \\
\text { Died, } 24 \text { hours } \\
\text { Died, } 24 \text { hours } \\
\text { Died, } 24 \text { hours }\end{array}$ \\
\hline
\end{tabular}

Mice were injected intraperitoneally with 32 M.L.D. of the lung poison 2 hours after the administration of the drug. Controls receiving the drugs alone survived. Controls receiving pneumonic lung extract alone died in 24 hours. 
TABLE 9

Neutralizing Power of Cinchona Derivatrves for the Toxicity of Pneumonic EXUdATE IN RABBits

\begin{tabular}{|c|c|c|c|}
\hline $\begin{array}{l}\text { Weight } \\
\text { of } \\
\text { Animal }\end{array}$ & Cinchona Derivative & $\begin{array}{l}\text { Dose of } \\
\text { Cinchona in } \\
\text { Grams per } \\
60 \text { Kilo }\end{array}$ & Results \\
\hline $\begin{array}{r}1280 \\
1460 \\
1300 \\
1040 \\
750 \\
1200\end{array}$ & 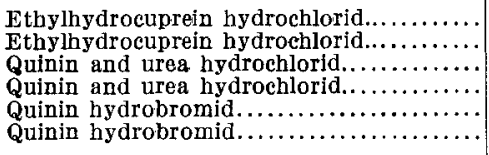 & $\begin{array}{l}0.5 \\
0.2 \\
0.5 \\
0.2 \\
0.5 \\
0.2\end{array}$ & $\begin{array}{l}\text { Died in } 24 \text { hours } \\
\text { Died in } 24 \text { hours } \\
\text { Died in } 24 \text { hours } \\
\text { Died in } 24 \text { hours } \\
\text { Died in } 24 \text { hours } \\
\text { Survived }\end{array}$ \\
\hline
\end{tabular}

Rabbits were injected into the muscle of the leg-quinin and toxin being given simultaneously in opposite legs. The dose of poison was uniformly 1 e'c per kilo. Controls receiving the doses of quinin alone survived.

Hemolytic Activity of Extracts of Human Pneumonic Lungs.-Using the technic described under the heading-pneumotoxin-it was found that the pneumonic lung extracts were markedly hemolytic for guinea-pig erythrocytes, the M.H.D. being in one case $0.3 \mathrm{c} c$ of a $1: 100$ dilution. Control experiments with normal (nonpneumonic) lungs were very slightly lytic in 1:50 dilution.

Summary of Antihemolytic Activity of Quinin Salts.-The results of the studies on the inhibitory effect of the cinchona derivatives on the hemolytic activity of pneumonic exudates were very difficult of interpretation. Using dilutions of these salts in doses ranging from 0.00001 to $0.002 \mathrm{gm}$. and 1 M.H.D. of poison we found that ethylhydrocuprein hydrochlorid, quinin, and urea hydrochlorid, gave a slight inhibition when large doses (of themselves hemolytic) were used. Quinin hydrochlorid, quinin hydrobromid, quinin bisulphate, and hydroquinin hydrochlorid behaved in a reverse way, giving marked inhibition in nonlytic doses and no inhibition in lytic doses. The ease of precipitation of the former salts in the presence of protein solutions and the greater solubility of the latter in protein solutions are factors entering into an explanation of this phenomenon. Sherwood ${ }^{5 \bar{x}}$ has recently studied this subject.

The Occurrence of Toxic Substances in the Blood of Pneumonic Patients.Attempts to detect toxic substances in the blood of pneumonic patients have been made by numerous workers. Cole ${ }^{6}$ has shown that the filtered active serum of a rabbit dying of a very severe pneumococcic septicemia does not contain any demonstrable toxins. Knowing that the Berkefeld filter retains toxic albumins, complement and various large protein molecules ${ }^{56,57}$ we repeated this experiment, using the unfiltered serum but were unable to produce anaphylactic symptoms in a rabbit. Rosenow, on the other hand, has obtained anaphylactic reactions by the primary injection of pneumonic serum which was allowed to autolyze at ice-box temperature for one week.

Since pneumococcic septicemia in rabbits and mice differs greatly from lobar pneumonia in man, we thought it might be possible to detect in human blood toxic substances derived either from the autolysis of the pneumococci or the leukocytes, or more particularly from the diffusion of toxic proteoses

55 Jour. Infect. Dis., 1917, 20, p. 185.

so Vaughan, V. C.: Protein split products in relation to immunity and disease, 1913.

57 Madsen, Th., and Noguchi, H.: Jour. Exper. Med., 1907, 9, p. 18. 
and albumoses into the circulation. With this object in view, we injected the whole blood, defibrinated blood, red blood cells, leukocytes and serum of normal persons and of patients suffering with lobar pneumonia-often moribund or at the height of the disease. These experiments were done on rabbits, rats and mice by both intravenous and intraperitoneal routes. Using graded doses calculated per body weight of the animal, we were unable to detect any difference in the toxicity of normal and pneumonic blood. Table 1 shows our results with active serums. The normal serum (taken from a healthy medical student) seems to be more toxic than the pneumonic. The pneumonic blood (Table 1) was taken from a patient with a temperature of $102 \mathrm{~F}$., pulse 128 to 140 , respiration 40 to 65 ; consolidation of lower right lobe; increased tactile fremitus, vocal resonance, bronchial breathing; no quinin was given.

TABLE 10

Comparative Toxicity for Mice of Normal Pneumonic Serums

\begin{tabular}{|c|c|c|c|c|c|}
\hline \multicolumn{3}{|c|}{ Normal } & \multicolumn{3}{|c|}{ Pneumonic } \\
\hline $\begin{array}{c}\text { Weight } \\
\text { in } \\
\text { Grams }\end{array}$ & $\begin{array}{l}\text { Dose } \\
\text { in CO } \\
\text { per Kilo }\end{array}$ & Results & $\begin{array}{l}\text { Weight } \\
\text { in } \\
\text { Grams }\end{array}$ & $\begin{array}{c}\text { Dose } \\
\text { in C C } \\
\text { per Kilo }\end{array}$ & Results \\
\hline $\begin{array}{l}16 \\
20 \\
19 \\
15 \\
16 \\
15 \\
20 \\
17\end{array}$ & $\begin{array}{r}1 \\
2 \\
6 \\
10 \\
12 \\
15 \\
20 \\
50\end{array}$ & $\begin{array}{c}\text { Survived } \\
\text { Died, } 48 \text { hours } \\
\text { Died, } 48 \text { hours } \\
\text { Died, } 72 \text { hours } \\
\text { Survived } \\
\text { Died, } 48 \text { hours } \\
\text { Died, } 48 \text { hours } \\
\text { Survived }\end{array}$ & $\begin{array}{l}16 \\
18 \\
14 \\
17 \\
13 \\
18 \\
23\end{array}$ & $\begin{array}{r}1 \\
2 \\
6 \\
10 \\
15 \\
20 \\
50\end{array}$ & $\begin{array}{l}\text { Survived } \\
\text { Survived } \\
\text { Survived } \\
\text { Survived } \\
\text { Survived } \\
\text { Survived } \\
\text { Survived }\end{array}$ \\
\hline
\end{tabular}

Mice were injected intraperitoneally with the sterile, active serum in proper dilution.

\section{THE INCREASED TOLERANCE FOR QUININ IN PNEUMONIA}

To begin an attack on the problem from another angle, a number of observations were made to determine whether or not the pneumococcus protein or substances present in the blood of pneumonia patients would exert any neutralizing influence in relation to cinchona poisoning.

The method consisted of mixing lethal doses of various quinin salts with nontoxic doses of pneumococcus protein or of pneumonic blood fractions (red blood cells, leukocytes, defibrinated blood, etc.) and incubating for one hour or more at $37 \mathrm{C}$. As pneumococcus protein, the washed and killed pneumococci obtained by centrifuging $500 \mathrm{cc}$ of a 48-hour broth culture were used suspended in $20 \mathrm{cc}$ salt solution. The mixtures were injected intraperitoneally into mice and rats. Several of the tests were done by injecting the dose of cinchona 3 or 4 hours after the administration of the pneumonic substance.

The work was repeated several times, but our results were uniformly negative with this method. 
TABLE 11

The Neutralizing Power of Pneumococcic Protein and of Pneumonic Serum for the Toxicity of Cinchona Derivatives

\begin{tabular}{|c|c|c|c|c|c|}
\hline $\begin{array}{l}\text { Weight } \\
\text { in } \\
\text { Grams }\end{array}$ & Substance & $\begin{array}{c}\text { Dose } \\
\text { in C C } \\
\text { per } \\
\text { Kilo }\end{array}$ & Cinchona Salt & $\begin{array}{c}\text { Dose of } \\
\text { Drug in } \\
\text { Grams } \\
\text { per Kilo }\end{array}$ & Results \\
\hline 12 & $\begin{array}{l}\text { Pneumococeus } \\
\text { protein }\end{array}$ & 10 & $\begin{array}{c}\text { Ethylhydrocuprejn } \\
\text { hydrochlorid }\end{array}$ & 0.7 & Died, 24 hours \\
\hline 17 & $\begin{array}{l}\text { Pneumococeus } \\
\text { protein }\end{array}$ & 10 & $\begin{array}{l}\text { Ethylhydrocuprein } \\
\text { hydrochlorid }\end{array}$ & 0.5 & Died, 24 hours \\
\hline 17 & $\begin{array}{l}\text { Pneumococeus } \\
\text { protein }\end{array}$ & 10 & $\begin{array}{l}\text { Quinin and urea } \\
\text { hydrochlorid }\end{array}$ & 0.7 & Died, 24 hours \\
\hline 23 & $\begin{array}{l}\text { Pneurnococcus } \\
\text { protein }\end{array}$ & 10 & $\begin{array}{l}\text { Quinin and urea } \\
\text { hydrochlorid }\end{array}$ & 0.5 & Died, 24 hours \\
\hline 20 & $\begin{array}{l}\text { Pneumonic } \\
\text { serum }\end{array}$ & 100 & $\begin{array}{l}\text { Quinin and urea } \\
\text { bydrochlorid }\end{array}$ & 0.5 & Died, 10 minutes \\
\hline 15 & $\begin{array}{l}\text { Pneumonic } \\
\text { serum }\end{array}$ & 50 & $\begin{array}{l}\text { Quinin and urea } \\
\text { hydrochlorid }\end{array}$ & 0.5 & Died, 10 minutes \\
\hline 14 & $\begin{array}{l}\text { Prteumonic } \\
\text { serum }\end{array}$ & 10 & $\begin{array}{l}\text { Quinin and urea } \\
\text { hydrochlorid }\end{array}$ & 0.5 & Died, 10 minutes \\
\hline
\end{tabular}

Emulsion of dead pneumococei mixed with dose of drug was incubated at 37 C. for 3 hours and injected intraperitoneally into mice. Controls receiving emulsion alone survived. Pneumonie serum, sterile and active, was injected intraperitoneally 4 hours before the administration of the drug.

\section{DISCUSSION}

While our results on the study of the influence of quinin and urea hydrochlorid, ethylhydrocuprein hydrochlorid, and allied cinchona derivatives on the toxic substances obtainable from virulent pnetımococci and pneumonic lungs have been largely negative, the question as to the rôle of quinin in the treatment of pnetumonia is still to be solved. As to the particular problems here reported on, more refined methods of study are to be devised. The action, if any, is not of a gross physical or chemical order. Suggestive are the exceptional action of quinin hydrobromid in combating the toxicity of pneumonic lung exudate, and the somewhat paradoxical results of various cinchona derivatives in antagonizing the hemolytic action of the same substance. Further research in many directions is here indicated. It may be added parenthetically that quinin hydrobromid and quinin dehydrobromid have proved of considerable clinical usefulness in the treatment of lobar pneumonia in man - a usefulness especially marked in Type II infections. The high pneumococcidal value of these salts was set forth in our first study. ${ }^{58}$ We have shown elsewhere that quinin exerts a highly specific and marked pneumococcidal action both in vitro and vivo. ${ }^{58}$ We have demonstrated its power of enhancing phagocytosis. ${ }^{59}$ Its

58 Solis-Cohen, S., Kolmer, J. A., and Heist, G. D.: Jour. Infect. Dis., 1917, 20, p. 40.

59 Ibid., p. 101. 
property of reducing the plane of nitrogen metabolism described by von Boeck $^{60}$ and its general influence on antibody production may be the factors involved. We are at present studying the latter problem.

\section{SUMMARY}

Pneumococci when dissolved in sodium choleate liberate a preformed endocellular toxin which is lytic for erythrocytes. Our work confirms the observations of Cole.

The liberation of this toxin in vitro is a most inconstant phenomenon and is fraught with many technical difficulties.

Different preparations of the pneumotoxin vary considerably in their toxicity for guinea-pigs, mice and rats. Anaphylactic shock followed by immediate or delayed death, very severe dyspnea with recovery or only mild respiratory disturbances with death in 24 hours are observed after the intravenous injection into guinea-pigs (200$300 \mathrm{gm}$. in weight) of doses varying from 9-2 $\mathrm{c} \mathrm{c}$ of the pneumotoxin.

Rats are highly resistant to the pneumotoxin. This is in accord with the findings of Novy.

The hemolytic power of the pneumotoxin was studied, using guinea-pig erythrocytes. It was observed to be inconstant and not always concomitant with the degree of toxicity.

Quinin and urea hydrochlorid, ethylhydrocuprein hydrochlorid, and other derivatives of cinchona were found to exert no influence on either the toxicity or the hemolytic activity of pneumotoxin.

Extracts of pneumonic lungs in the stage of gray hepatization were prepared and found to be extremely toxic for guinea-pigs and rabbits on intravenous and intramuscular injection. Convulsions, dyspnea and immediate death followed the intravenous injection of guinea-pigs and rabbits with doses of $0.7 \mathrm{cc}$ and $0.2 \mathrm{c}$, respectively, per kilo of body weight.

Therapeutic doses of quinin bisulphate, quinin hydrochlorid and particularly quinin hydrobromid prolonged to a recognizable extent the lives of animals receiving 1 M.L.D. of pneumonic lung extract.

These pneumonic lung extracts were found to be markedly lytic for erythrocytes, the M.H.D. being about $0.3 \mathrm{c} \mathrm{c}$ of a $1: 100$ dilution with the technic employed.

Quinin and urea hydrochlorid and ethylhydrocuprein hydrochlorid had slight inhibitory effect on the hemolytic activity of the lung

6o Untersuchungen über die Zersetzung des Eiweisses im Thierkörper unter dem Einflusse von Morphin, Chinin und Arsenige Säure, 1871. 
extracts when large, hemolytic doses of the drugs were used. Quinin hydrochlorid, quinin hydrobromid, quinin bisulphate, and hydroquinin hydrochlorid behaved in a reverse way, exhibiting marked inhibition in nonhemolytic doses and no inhibition in hemolytic doses.

Substances toxic for rabbits, rats or mice could not be demonstrated in the blood of patients suffering with lobar pneumonia.

Neither pneumococcus protein nor pneumonic blood was found to have any neutralizing action on the toxicity of quinin salts for animals.

We regard as a tenable hypothesis, the view that the pneumotoxin may have the specific role of increasing the permeability of the walls of the capillaries lining the alveoli, for the various normal blood proteins, erythrocytes, leukocytes, fibrin and enzymes which go to make up the pneumonic lung exudate; and that it furthermore tends to inhibit the autolysis initiated by the proliferatig pneumococci, thus producing toxic albumoses, proteoses and peptones. At the crisis this inhibitory action is changed to an accelerating one and resolution then commonly follows.

Neither the clinically beneficial action of cinchona derivatives in the pneumonias nor the increased quinin tolerance of pneumonia patients receives elucidation from the experiments reported; the results being largely negative. Certain suggestive phenomena were observed that further study may elucidate. That cinchona derivatives are specifically pneumococcidal and that they increase phagocytic activity has been shown in previous papers. Whether their influence on general metabolism and on general antibody production will suffice to explain their further protective and curative influence remains to be determined. 